Franciszek Mróz

Uniwersytet Pedagogiczny w Krakowie, Polska - Pedagogical University of Cracow, Poland

\title{
Przedsiębiorczość jako czynnik rozwoju Camino de Santiago w Polsce
}

\section{Entrepreneurship as a Factor in the Development of Camino de Santiago in Poland}

Streszczenie: W 2003 r. europejska sieć Camino de Santiago - Drogi św. Jakuba - dotarła do granicy niemiecko-polskiej w Görlitz - Zgorzelec. W następnym roku grupa miłośników Szlaku Jakubowego w Polsce rozpoczęła prace nad wytyczeniem i oznakowaniem pierwszych polskich odcinków szlaku pielgrzymkowego do Santiago de Compostela. W kolejnych latach w wielu regionach Polski pojawiały się inicjatywy oznakowania nowych odcinków Drogi św. Jakuba. Finałem tych projektów jest imponująca liczba 34 oznakowanych polskich odcinków Szlaku św. Jakuba, które łącznie tworzą sieć Camino de Santiago o długości ponad $6460 \mathrm{~km}$. Przedmiotem badań omówionych w niniejszym artykule były wybrane odcinki Drogi św. Jakuba znajdujące się właśnie na terenie Polski. Badania terenowe przeprowadzono w latach 2006-2017 na 12 takich odcinkach. W sumie, w czasie pieszej wędrówki, przebadano ponad $1200 \mathrm{~km}$ Szlaku św. Jakuba. Celem badań było poznanie przemian, które zaszły w sektorze usług turystycznych na wybranych polskich odcinkach Drogi św. Jakuba, a także przeanalizowanie działań przedsiębiorczych podejmowanych przez władze samorządowe, stowarzyszenia i organizacje turystyczne, bractwa i stowarzyszenia św. Jakuba, a także przedsiębiorców w celu rozwoju ruchu pielgrzymkowego, turystyki religijnej i turystyki kulturowej na badanych szlaku. W przedstawieniu wyników badań posłużono się przede wszystkim metodą opisowo-analityczną, kartograficznymi metodami prezentacji danych, a także metodami statystycznymi. Wyniki badań wskazują, że projektowanie, wytyczanie i oznakowanie 34 polskich odcinków Camino de Santiago jest przede wszystkim zasługą grup miłośników Drogi św. Jakuba, caminowiczów, członków bractw św. Jakuba, stowarzyszeń Jakubowych oraz duszpasterzy. W zdecydowanej większości była to inicjatywa oddolna i wyraz społecznej przedsiębiorczości dziesiątek osób. Dopiero na kolejnych etapach rozwoju Drogi św. Jakuba w poszczególnych regionach stopniowo w „projekty caminowe” włączały się władze samorządów terytorialnych.

\footnotetext{
Abstract: In 2003 the European network of Camino de Santiago - Way of St. James reached the border between Germany and Poland in Görlitz - Zgorzelec. In the following year, a group of fans of the Way of St. James in Poland started activities aimed at setting out and marking the first Polish sections of the pilgrimage route to Santiago de Compostela. In the next years, many regions of Poland witnessed initiatives of marking new sections of the Way of St. James. The projects were finalised with an impressive number of 34 marked Polish sections of the Way of St. James which jointly made the network of Camino de Santiago of a length of more than $6,460 \mathrm{~km}$. Selected sections of the Way of St. James in
} 
Poland constitute the subject of research. Field studies were conducted during the years 2006-2017 in twelve Polish sections of Camino de Santiago. A length of more than 1,200 kilometres of the Route of St. James was examined (by walking). The objective of the research was to learn about transformations in the sector of tourism services which occurred on selected Polish sections of the Way of St. James and to analyse entrepreneurial activities undertaken both by local government authorities, tourism associations and organisations, Brotherhoods and Associations of St. James, and businesses in order to develop pilgrimage movements, religious tourism and cultural tourism on the analysed route. When presenting research results, mainly the descriptive and analytical method, cartographic presentations methods and statistical methods have been used. The conducted research has shown that the designing, setting out and marking of 34 Polish sections of Camino de Santiago is mainly the contribution of groups of fans of the Way of St. James, Camino pilgrims, members of the Brotherhoods of St. James and Associations of St. James, and priests. In the majority of cases, this was a "grassroots" initiative and an expression of social entrepreneurship of dozens of people. It was only at subsequent stages of the development of the Way of St. James in individual regions that local government authorities gradually joined "Camino" projects.

Słowa kluczowe: Camino de Santiago; Droga św. Jakuba; pielgrzymowanie; przedsiębiorczość; turystyka religijna

Keywords: Camino de Santiago; entrepreneurship; pilgrimages; religious tourism; Way of St. James

Otrzymano: 25 października 2017

Received: 25 October 2017

Zaakceptowano: 10 maja 2018

Accepted: 10 May 2018

\section{Sugerowana cytacja/Suggested citation:}

Mróz, F. (2018). Przedsiębiorczość jako czynnik rozwoju Camino de Santiago w Polsce. Przedsiębiorczość-Edukacja [Entrepreneurship-Education], 14,292-312.DOI: 10.24917/20833296.14.22

\section{Wstęp}

Prowadząca do grobu św. Jakuba Starszego Apostoła w Santiago de Compostela Droga św. Jakuba (Camino de Santiago) należy do najważniejszych, chrześcijańskich szlaków pielgrzymkowych. Jest to także (od 1987 r.) pierwszy Europejski Szlak Kulturowy. W ostatnim dwudziestoleciu najpiękniejsza droga świata - jak bardzo często określa się szlak pątniczy do Composteli - przeżywa ogromy rozwój. Na imponujący renesans tego średniowiecznego traktu pielgrzymkowego wpływ miało szereg czynników zarówno religijnych, jak i społeczno-ekonomicznych, kulturowych oraz politycznych. W $1993 \mathrm{r}$. UNESCO wpisało Drogę św. Jakuba na terytorium Hiszpanii, a w 1998 r. na obszarze Francji na Listę światowego dziedzictwa UNESCO. W 2015 r. wpis ten został poszerzony o liczące ponad $1500 \mathrm{~km}$ odcinki Camino de Santiago w północnej Hiszpanii ${ }^{1}$. W ostatnich latach sankturium św. Jakuba w Santiago de Compostela odwiedza ponad $5 \mathrm{mln}$ turystów rocznie. Z każdym rokiem wzrasta liczba osób, którzy do grobu pierwszego męczennika wśród Apostołow przybywają pieszo, rowerem, konno, a także na wózku inwalidzkim. W 2016 r. w Biurze Pielgrzymkowym Arcybiskupstwa Santiago de Compostela zarejestrowano rekordową liczbę 277854 osób, które otrzymały Compostelkę - dokument potwierdzający przejścia pieszo ostatnich $100 \mathrm{~km}$ Drogi św. Jakuba (do katedry

\footnotetext{
${ }^{1}$ www.whc.unesco.org/en/list/669/ (2017, 12 października)
} 
w Santiago de Compostela) lub przejechania 100 km szlaku konno bądź 200 km na rowe$\mathrm{rze}^{2}$. Z każdym rokiem w wielu krajach Europy powstają nowe projekty, których celem jest utworzenie nowych odcinków Camino de Santiago i rozwój tego wyjątkowego szlaku.

W 2003 r. europejska sieć szlaków pielgrzymkowych do Santiago de Compostela dotarła do granicy niemiecko-polskiej w Görlitz - Zgorzelec (Mróz, 2017). Od tego momentu grupa miłośników Camino de Santiago w Polsce i osób, które odbyły już pielgrzymkę do grobu św. Jakuba, rozpoczęła prace nad wytyczeniem i oznakowaniem pierwszych polskich odcinków Drogi św. Jakuba. W kolejnych latach w wielu regionach Polski rodziły się inicjatywy oznakowania nowych odcinków Camino de Santiago. Finałem tych projektów jest imponująca liczba 34 oznakowanych polskich odcinków, które łącznie tworzą sieć Camino de Santiago o długości ponad 6460 km. W dalszym ciągu w wielu regionach Polski realizowane są kolejne projekty związane $\mathrm{z}$ wytyczeniem i oznakowaniem nowych odcinków Szlaku Jakubowego.

Przedmiotem badań omówionych w niniejszym artykule były wybrane odcinki Camino de Santiago znajdujące się na terenie Polski. Badania terenowe przeprowadzono w latach 2006-2017 na 12 odcinkach Drogi św. Jakuba, tj. na: Drodze Polskiej (Camino Polaco - odcinek Ogrodniki - Święta Lipka), Beskidzkiej Drodze św. Jakuba, Dolnośląskiej Drodze św. Jakuba, Lubelskiej Drodze św. Jakuba, Małopolskiej Drodze św. Jakuba, Mazowieckiej Drodze św. Jakuba, Miechowskiej Drodze św. Jakuba, Podkarpackiej Drodze św. Jakuba Via Regia, Nyskiej Drodze św. Jakuba, Pomorskiej Drodze św. Jakuba, Sudeckiej Drodze św. Jakuba oraz Świętokrzyskiej Drodze św. Jakuba. W sumie podczas pieszych wędrówek przebadano ponad $1200 \mathrm{~km}$ polskich odcinków Drogi św. Jakuba. W trakcie badań przeprowadzono wywiady z liderami - opiekunami poszczególnych odcinków, a także prezesami wszystkich bractw św. Jakuba w Polsce oraz członkami klubów przyjaciół Drogi św. Jakuba w Polsce. Autor opracowania od 2007 r. jest zaangażowany w realizację projektów, których celem jest wytyczenie i oznakowanie, a obecnie - rozwój Małopolskiej Drogi św. Jakuba.

Celem podjętych badań było poznanie przemian, które zaszły w sektorze usług turystycznych na wybranych polskich odcinkach Drogi św. Jakuba, a także przeanalizowanie działań przedsiębiorczych podejmowanych przez władze samorządowe, stowarzyszenia i organizacje turystyczne, bractwa i stowarzyszenia św. Jakuba, duszpasterzy i władze kościelne, a także przedsiębiorców i mieszkańców regionów, przez które przebiega Droga św. Jakuba w celu rozwoju ruchu pielgrzymkowego, turystyki religijnej i turystyki kulturowej na badanych szlakach.

W przedstawieniu wyników badań posłużono się przede wszystkim metodą opisowo-analityczną, kartograficznymi metodami prezentacji danych, a także metodami statystycznymi.

\section{Przedsiębiorczość jako czynnik powstania polskich odcinków Camino de Santiago}

Polskie odcinki Drogi św. Jakuba tworzą sieć najdłuższego szlaku zarówno pielgrzymkowego, jak i kulturowego w kraju. Ponad 6460 km odcinków Camino de Santiago w Polsce jest powiązanych z europejską siecią szlaków prowadzących do grobu św. Jakuba w Santiago de Compostela. Droga św. Jakuba w Polsce łączy się bowiem z odcinkami Szlaku

\footnotetext{
${ }^{2}$ https://oficinadelperegrino.com/estadisticas/ (2017, 15 października)
} 
Jakubowego: w Rosji - w obwodzie kaliningradzkim (Pomorska Droga św. Jakuba - od polsko-rosyjskiego drogowego przejścia granicznego Gronowo - Mamonowo), na Litwie (Droga Polska - od polsko-litewskiego drogowego przejścia granicznego Ogrodniki Lazdijai), na Ukrainie (Podkarpacka Droga św. Jakuba Via Regia - od polsko-ukraińskiego drogowego przejścia granicznego Medyka - Szeginie), w Słowacji (Beskidzka Droga św. Jakuba - od granicy polsko-słowackiej na Eliaszówce), w Czechach (Beskidzka Droga św. Jakuba, Kłodzka Droga św. Jakuba i Nyska Droga św. Jakuba) oraz w Niemczech (Dolnośląska Droga św. Jakuba, Droga św. Jakuba Via Regia, Lubuska Droga św. Jakuba i Pomorska Droga św. Jakuba) (ryc. 1; Mróz, 2015).

Należy bardzo wyraźnie podkreślić, że projektowanie, wytyczanie i oznakowanie 34 polskich odcinków Drogi św. Jakuba jest przede wszystkim zasługą grup miłośników Drogi św. Jakuba, caminowiczów - tj. osób, które odbyły pielgrzymkę - wędrówkę do Composteli, członków bractw św. Jakuba i stowarzyszeń Jakubowych oraz duszpasterzy. W zdecydowanej większości była to więc inicjatywa oddolna i wyraz społecznej przedsiębiorczości dziesiątek osób. Dopiero na kolejnych etapach rozwoju Drogi św. Jakuba w poszczególnych regionach stopniowo w "projekty caminowe” włączały się władze samorządów terytorialnych - na szczeblu gminnym, powiatowym oraz wojewódzkim. Warto również zaznaczyć, że te nieformalne grupy osób wytyczających i znakujących odcinki Szlaku Jakubowego w Polsce zaczęły z czasem formalizować swoją działalność przez zakładanie bractw św. Jakuba, stowarzyszeń i organizacji Jakubowych o charakterze religijnym, religijno-świeckim lub świeckim (Tab. 1; Mróz Ł., 2016). Dla porównania, w Hiszpanii renesans ruchu pielgrzymkowego i rozwój turystyki religijnej do Santiago de Compostela był wynikiem działań podjętych początkowo przede wszystkim przez hiszpańską federację stowarzyszeń przyjaciół Camino de Santiago (Federación Española de Asociaciones de Amigos del Camino de Santiago), a następnie przez hiszpańskie władze rządowe oraz władze regionów autonomicznych, przez które przebiega Camino Francés - Droga Francuska. W projekty nad odtworzeniem i oznakowaniem odcinków Camino de Santiago oraz w rozbudowę infrastruktury turystycznej włączyły się także hiszpańskie Ministerstwa: Infrastruktury, Kultury oraz Transportu, Turystyki i Komunikacji (Mróz F., 2016b). W przypadku Hiszpanii o rozwoju potencjału turystyczno-kulturowego Drogi św. Jakuba zadecydowała zatem przede wszystkim przedsiębiorczość administracyjna - realizowana w sektorze publicznym - oraz przedsiębiorczość gospodarcza.

Obecnie opiekę nad poszczególnymi odcinkami Szlaku Jakubowego sprawują w większości członkowie bractw św. Jakuba, członkowie stowarzyszeń i klubów miłośników Camino, caminowicze oraz duszpasterze - księża pracujący w parafiach lub placówkach kościelnych położonych przy szlaku. Poza Hiszpanią tylko w Polsce obserwuje się w ostatnim dziesięcioleciu tak dynamicznie rozrastającą się sieć Camino de Santiago, wzrastającą liczbę innowacyjnych projektów związanych z rozwojem Drogi św. Jakuba, a także stale rosnący kult św. Jakuba Apostoła w układach przestrzennych. Bez wątpienia Polska jest dzisiaj w grupie liderów caminowych w Europie (Mróz, 2017).

Pierwszym odcinkiem Camino de Santiago w Polsce, otwartym 24 lipca 2005 r. w Jakubowie oraz w Zgorzelcu, jest Dolnośląska Droga św. Jakuba (Głogów - Jakubów - Grodowiec - Lubań - Zgorzelec). Szlak ten powstał głównie z inicjatywy Bractwa św. Jakuba Apostoła w Jakubowie (tab. 1; ryc. 1), którego głównym celem było wytyczenie szlaku pielgrzymkowego prowadzącego do kościoła w Jakubowie, a następnie opieka i nadzór 
Ryc. 1. Drogi św. Jakuba w Polsce (stan na 25.10.2017 r.)

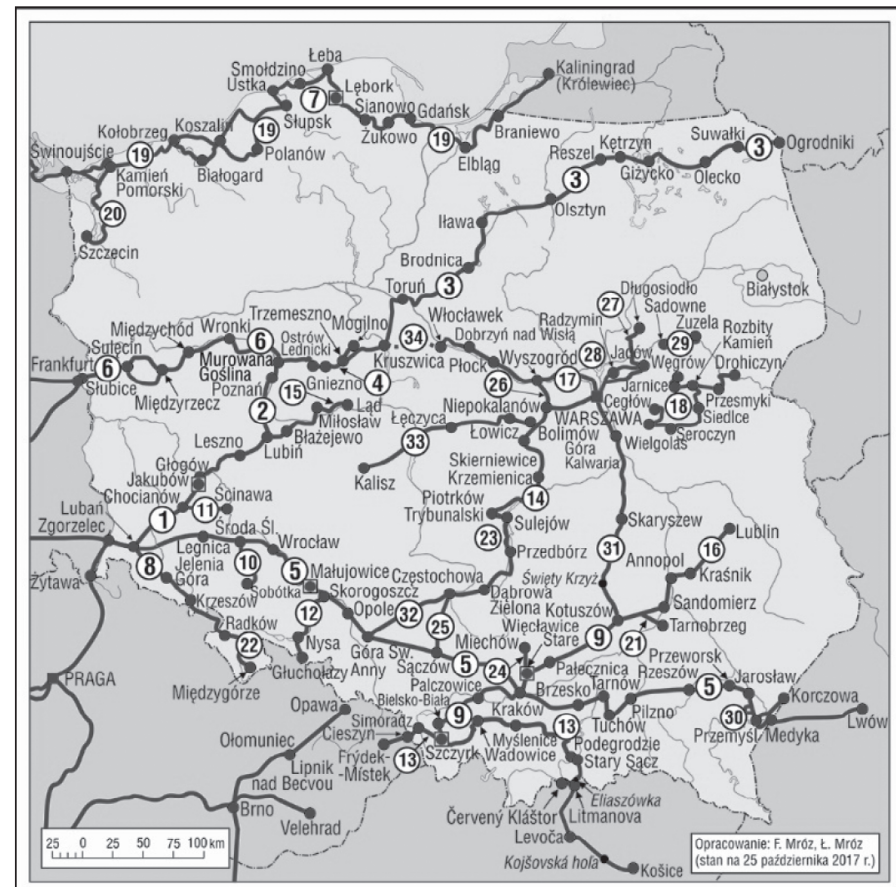

Drogi św. Jakuba Apostoła Starszego w Polsce

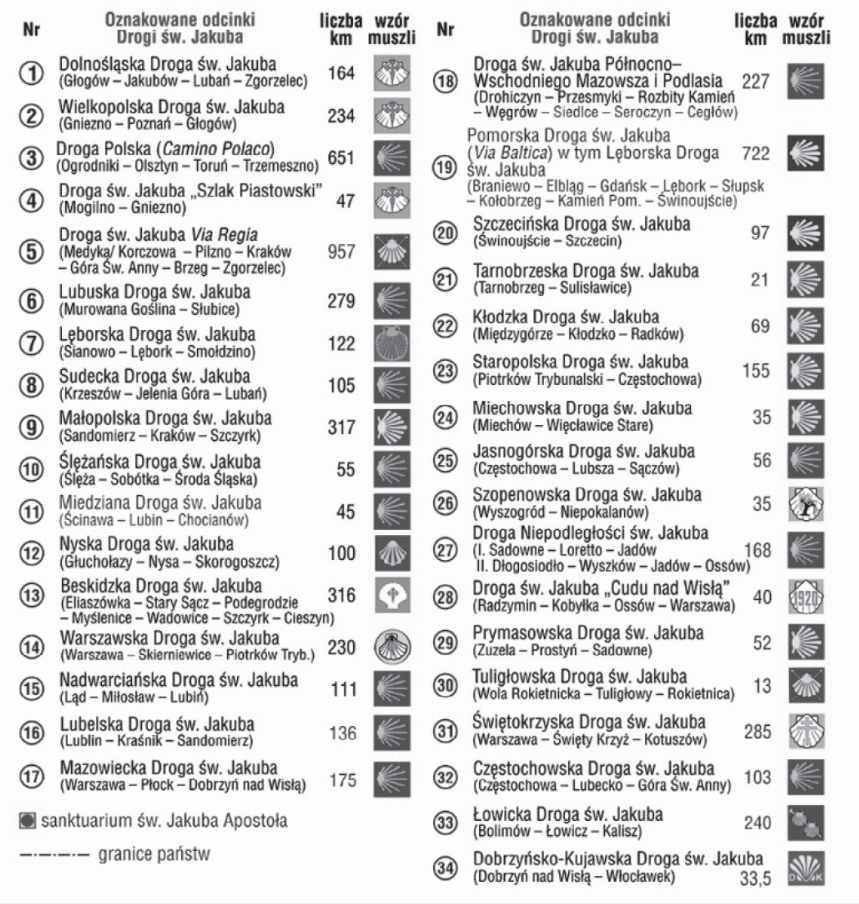

Źródło: Mróz F., Mróz Ł. (2017) 
nad tym szlakiem. W prace nad oznakowaniem szlaku włączyły się także: Fundacja Wioski Franciszkańskiej w Janicach k. Jeleniej Góry, Klub Inteligencji Katolickiej w Głogowie, Towarzystwo Ziemi Głogowskiej, Związek Gmin Zagłębia Miedziowego oraz lokalne samorządy i parafie, przez które przebiega droga. W 2007 r. wzdłuż Dolnośląskiej Drogi św. Jakuba, lecz w kierunku przeciwnym, ze Zgorzelca do Jakubowa, został wytyczony Szlak Pielgrzymkowy do Jakubowa (Hass, 2008; Mróz, 2015).

Już w 2004 r. na forum internetowym portalu Polskiego Klubu Camino de Santiago zaprezentowano projekt wytyczenia i oznakowania Drogi Polskiej (Camino Polaco), której trasa połączyłaby dwa kościoły pw. św. Jakuba - w Olsztynie i w Toruniu. Koncepcję tego szlaku przedstawił Włodzimierz Antkowiak - założyciel Polskiego Klubu Camino de Santiago, artysta malarz, poeta i autor jednej z pierwszych współczesnych polskich relacji z pielgrzymki do Composteli (Antkowiak, 2007). Prace nad oznakowaniem pierwszego z odcinków Camino Polaco zrealizowali członkowie Stowarzyszenia na rzecz Ratowania Zabytków Kultury Europejskiej w Polsce - organizacji pozarządowej zarejestrowanej w 2005 r. w Toruniu. Dwudziestokilometrowy odcinek Drogi Polskiej, prowadzący z katedry pw. św. Jakuba w Olsztynie do sanktuarium maryjnego w Gietrzwałdzie, otwarto 25 lipca 2006 r. W kwietniu 2007 r. szlak ten został przedłużony z Gietrzwałdu do kościoła św. Jakuba w Toruniu, a w 2009 r. - z Torunia do Trzemeszna (Mendyk, Mróz, 2009). Oznakowania kolejnych odcinków szlaku (Iława - Toruń - Kruszwica) dokonali znakarze z Oddziału Miejskiego PTTK im. Mariana Sydowa w Toruniu pod przewodnictwem Henryka Miłoszewskiego ${ }^{3}$, przy wsparciu finansowym władz Torunia, Brodnicy, Kurzętnika i Kruszwicy (Bielicki, Roszak, 2012). Wytyczenie i oznakowanie 313 km Drogi Polskiej wiodącej od polsko-litewskiego drogowego przejścia granicznego Ogrodniki Lazdijai do Olsztyna (odcinki o nazwie „Suwalszczyzna” oraz „Warmia i Mazury”) to z kolei zasługa członków Bractwa Pielgrzymkowego św. Jakuba w Kętrzynie. Ten fragment Camino Polaco został uroczyście otwarty 25 lipca 2011 r. w Kętrzynie.

Małopolska Droga św. Jakuba, której trasa prowadzi z Sandomierza przez Kraków do Szczyrku, została wytyczona i oznakowana przez członków Bractwa św. Jakuba w Więcławicach Starych, sandomierskich i tarnobrzeskich przewodników PTTK, członków Polskiego Towarzystwa Tatrzańskiego w Tarnobrzegu, ks. kan. Jerzego Sobczyka - proboszcza Parafii pw. św. Jakuba w Kotuszowie - oraz mieszkańców Parafii pw. św. Jakuba w Kotuszowie, Pałecznicy, Sance i Więcławicach Starych (Mróz, 2014).

Wytyczenie oraz oznakowanie Drogi św. Jakuba „Szlak Piastowski” (Mogilno - Trzemeszno - Niechanowo - Gniezno) jest z kolei zasługą Organizacji Turystycznej „Szlak Piastowski" i Fundacji Wioski Franciszkańskiej w Janicach. Fundacja Wioski Franciszkańskiej wytyczyła również inne odcinki Camino de Santiago w Polsce: odcinek Drogi św. Jakuba Via Regia z Góry św. Anny do Zgorzelca (Góra św. Anny - Wrocław - Zgorzelec), Wielkopolską Drogę św. Jakuba (Gniezno - Lednica - Poznań - Głogów), Via Cervimontana (Droga Jeleniogórska z Jeleniej Góry do Lubania), Ślężańską Drogę św. Jakuba (Ślęża - Sobótka - Środa Śląska). Via Cervimontana została w 2010 r. przedłużona o 50-kilometrowy odcinek z sanktuarium Matki Bożej Łaskawej w Krzeszowie k. Kamiennej Góry do Jeleniej Góry i obecnie nazywana jest Sudecką Drogą św. Jakuba (Mendyk, Mróz, 2009).

Kolejne odcinki Drogi św. Jakuba Via Regia zostały oznakowane przez członków Stowarzyszenia „Forum dla Zagłębia Dąbrowskiego” (na czele z jego prezesem Dariuszem

\footnotetext{
${ }^{3}$ http://www.pttk.torun.pl/Szl.\%C5\%9Bw.Jakuba\%20p\%C5\%82d.html (2017, 15 października)
} 
Jurkiem), Miłośników Ziemi Toszeckiej oraz członków Stowarzyszenia „Przyjaciele Dróg św. Jakuba w Polsce” (odcinek Kraków - Piekary Śląskie), mieszkańców Parafii pw. NMP Matki Kościoła i św. Jakuba w Brzesku oraz Pawła Plezię - przewodnika, prezes Zarządu Oddziału PTTK w Ropczycach (odcinek Tuchów - Tarnów - Brzesko - Kraków) oraz Krzysztofa Liebchena, Pawła Plezię, osoby ze Stowarzyszenia „Pro Carpathia”, a także członków Bractwa św. Jakuba Apostoła przy Sanktuarium Grobu Bożego w Przeworsku (Podkarpacka Droga św. Jakuba - odcinek Kroczowa/Medyka - Przemyśl - Jarosław Przeworsk - Łańcut - Rzeszów - Pilzno) (Hołub, Mróz, 2013). W 2014 r. członkowie Bractwa św. Jakuba w Przeworsku wspólnie ze Stowarzyszeniem na rzecz Rozwoju Tuligłów wytyczyli i oznakowali łącznikowy odcinek Podkarpackiej Drogi św. Jakuba - tzw. Tuligłowską Drogę św. Jakuba prowadzącą z Woli Rokietnickiej do sanktuarium Matki Bożej Dobrej Nadziei w Tuligłowach, a następnie do Rokietnicy, gdzie łączy się on z głównym traktem Drogi św. Jakuba Via Regia (13 km).

Otwarcie ostatniego odcinka Drogi św. Jakuba Via Regia (Medyka - Przemyśl) sprawiło, że szlak ten stał się najdłuższym polskim odcinkiem Camino de Santiago. Długość Drogi św. Jakuba Via Regia wynosi 957 km, a szlak ten łączy polsko-ukraińskie drogowe przejścia graniczne Medyka - Szeginie z granicą polsko-niemiecką na Moście Staromiejskim w Zgorzelcu - Görlitz.

Warto podkreślić, że oznakowanie Camino de Santiago do granicy polsko-ukraińskiej dało impuls do oznakowania Drogi św. Jakuba Via Regia na terenie Ukrainy. W dniach 10-11 października 2015 r. (tj. 10 lat po otwarciu pierwszego polskiego Camino de Santiago) w Szeginii i Medyce, przy granicy polsko-ukraińskiej połączono pierwszy - ukraiński odcinek Jakubowego Szlaku, tzw. Lwowską Drogę św. Jakuba Via Regia z polskim odcinkiem Camino de Santiago - Podkarpacką Drogą św. Jakuba Via Regia. Otwarcie Lwowskiej Drogi św. Jakuba Via Regia włączyło Ukrainę w europejską sieć szlaków pielgrzymkowych prowadzących do grobu św. Jakuba w Santiago de Compostela i zwiększyło europejską przestrzeń caminową. Ukraiński odcinek Camino de Santiago stwarza również szansę na rozwój ruchu pielgrzymkowego, turystyki religijnej i turystyki kulturowej na pograniczu polsko-ukraińskim (Mróz, Bordun, 2016).

Członkowie nieformalnej grupy działającej pod nazwą Miłosławski Klub Przyjaciół Nadwarciańskiej Drogi św. Jakuba przy wsparciu Stowarzyszenia „Przyjaciele Dróg św. Jakuba w Polsce” oznakowali 111-kilometrowy odcinek Nadwarciańskiej Drogi św. Jakuba. Oznakowanie tzw. Miedzianej Drogi św. Jakuba, a więc Szlaku Jakubowego w powiecie lubińskim, jest zasługą Mariana Hawrysza, prezesa Oddziału PTTK „Zagłębie Miedziowe” w Lubinie. Szlak ten ma długość $45 \mathrm{~km}$ i prowadzi przez Ścinawę, Ręszów, Siedlce, Czerniec, Lubin, Gorzyce, Brunów do Chocianowa, gdzie łączy się z Dolnośląską Drogą św. Jakuba.

Bardzo często wytyczenie i oznakowanie odcinków Drogi św. Jakuba w wybranych regionach Polski było zasługą kilkuosobowej grupy miłośników Camino de Santiago. W każdej z tych grup był lider, którego silna osobowość oraz umiejętność współpracy ze środowiskiem wewnętrznym i otoczeniem była kluczem do sukcesu, którym było otwarcie nowego odcinka szlaku muszli św. Jakuba (Zioło, 2012). Takim liderem w przypadku wytyczenia i oznakowania Beskidzkiej Drogi św. Jakuba był Dagobert Drost - przewodnik, znakarz i członek Bractwa św. Jakuba w Szczyrku. Do oznakowania Beskidzkiej Drogi św. Jakuba włączyli się także członkowie Bractwa św. Jakuba i Parafii pw. św. Jakuba w Szczyrku, parafianie Parafii pw. św. Jakuba w Simoradzu oraz miłośnicy Camino de 
Santiago w Beskidzie Sądeckim, Beskidzie Wyspowym, Beskidzie Makowskim, Beskidzie Małym i Beskidzie Śląskim.

Oznakowanie pierwszego odcinka Drogi św. Jakuba na Mazowszu, tj. Warszawskiej Drogi św. Jakuba (Warszawa - Piotrków Trybunalski; 229 km), jest z kolei zasługą dr. Jerzego Kazimierczaka - członka Konfraterni Świętego Apostoła Jakuba Starszego przy Katedrze Polowej Wojska Polskiego w Warszawie (Kazimierczak, 2015). Szlak Warszawskiej Drogi św. Jakuba został w 2014 r. przedłużony o kolejny odcinek noszący nazwę Staropolska Droga św. Jakuba (Piotrków Trybunalski - sanktuarium Matki Bożej Jasnogórskiej w Częstochowie; $155 \mathrm{~km}$ ). Inicjatorem oznakowania szlaku byli Grzegorz Bednarek i śp. Sylwester Krzesak, a oznakowanie w terenie wykonali: Piotr Michalak, Stanisław Smagieł, Jerzy Kazimierczak oraz Andrzej Siut z Włoszczowej. Drugi odcinek Drogi św. Jakuba na Mazowszu, tzw. Mazowiecką Drogę św. Jakuba, wiodącą z Bazyliki Archikatedralnej pw. Męczeństwa św. Jana Chrzciciela na Starym Mieście w Warszawie do Dobrzynia nad Wisłą, oznakowany został przez członków Stowarzyszenia „Przyjaciół Dróg św. Jakuba w Polsce” dzięki wsparciu finansowemu Samorządu Województwa Mazowieckiego. Dużym osiągnięciem było indywidualne oznakowanie dalszego odcinka Camino de Santiago na ziemi dobrzyńskiej - z Dobrzynia nad Wisłą do Włocławka. Szlak ten oznakował bowiem samodzielnie caminowicz Paweł Śliwiński w 2017 r. W następnym roku planował on wspólnie z grupą miłośników Drogi św. Jakuba znakowanie szlaku na odcinku z Włocławka przez Siniarzewo do Kruszwicy, gdzie Dobrzyńsko-Kujawska Droga św. Jakuba połączy się z Drogą Polską.

Przeprowadzona prezentacja przedsiębiorczości społecznej caminowiczów, członków bractw św. Jakuba i stowarzyszeń miłośników Drogi św. Jakuba byłaby niepełna bez podkreślenia bardzo prężnie działającej w ostatnich latach Konfraterni Świętego Apostoła Jakuba Starszego przy Katedrze Polowej Wojska Polskiego pw. Najświętszej Maryi Panny Królowej Polski w Warszawie. To dzięki pracy członków tego bractwa sieć Camino de Santiago rozrosła się nie tylko na Mazowszu, ale także w innych regionach Polski. W latach 2014-2017 członkowie Konfraterni wytyczyli i oznakowali następujące odcinki Drogi św. Jakuba w Polsce: Warszawską Drogę św. Jakuba (Warszawa - Piotrków Trybunalski), Mazowiecką Drogę św. Jakuba (Warszawa - Dobrzyń nad Wisłą), Szopenowską Drogę św. Jakuba (Wyszogród -Żelazowa Wola - Niepokalanów), Drogę św. Jakuba "Cudu nad Wisłą" (Radzymin - Kobyłka - Ossów - Katedra Polowa Wojska Polskiego w Warszawie), Prymasowską Drogę św. Jakuba (Zuzela - Prostyń - Sadowne), Świętokrzyską Drogę św. Jakuba (Warszawa - Góra Kalwaria - Warka - Świerże Górne - Skaryszew - Mirzec - Bodzentyn - Święty Krzyż - Kotuszów), Łowicką Drogę św. Jakuba (Bolimów - Łowicz - Kalisz) oraz Nadpilicką Drogę św. Jakuba - w sumie to ponad 1300 km Camino de Santiago (Bożek i in., 2015; Kazimierczak, 2015; Madej-Janiszek, 2015; Stefaniak, Wasiak, 2017).

Jak już wspomniano, wymienione wyżej odcinki Drogi św. Jakuba w Polsce powstały dzięki zaangażowaniu i wolontariackiej pracy dziesiątek prywatnych osób. Część z projektów związanych z oznakowaniem i promocją szlaku w poszczególnych jednostkach przestrzennych była finansowana ze środków władz samorządowych - zarówno na szczeblu gminnym, jak i powiatowym oraz wojewódzkim. W przypadku kilku odcinków ciężar wytyczenia, oznakowania i utrzymania wzięły na siebie w całości samorządy terytorialne. W takiej sytuacji możemy mówić o tzw. przedsiębiorczości administracyjnej. Dotyczy to m.in. Nyskiej Drogi św. Jakuba, która powstała dzięki Urzędowi Miasta Nysa, 
Kłodzkiej Drogi św. Jakuba - wytyczonej i oznakowanej w 2013 r. dzięki wsparciu finansowemu Samorządu Województwa Dolnośląskiego oraz Gminy Bystrzyca Kłodzka, a także Pomorskiej Drogi św. Jakuba. Zarząd Województwa Dolnośląskiego w 2010 r. podjął uchwałę, w której zakwalifikował odcinki Drogi św. Jakuba do najważniejszych szlaków kulturowych województwa. Samorządy województwa wielkopolskiego i lubuskiego dofinansowały oznakowanie i opis Lubuskiej Drogi św. Jakuba na terenie województwa wielkopolskiego i lubuskiego. Wytyczenie i zagospodarowanie tego odcinka Drogi św. Jakuba w powiecie sulęcińskim i słubickim wykonano w ramach projektu „Drogi św. Jakuba na pograniczu polsko-niemieckim - stworzenie transgranicznego systemu oznakowania i informacji”, współfinansowanego ze środków Europejskiego Funduszu Rozwoju Regionalnego, w ramach Programu Współpracy Transgranicznej Polska (woj. lubuskie) - Brandenburgia 2007-2013 (Szeszko, Góralczyk, 2015). Wsparcie finansowe na oznakowanie Drogi św. Jakuba Via Regia od Krakowa do Piekar Śląskich oraz przygotowanie przewodnika uzyskano od władz samorządowych miasta Piekary Śląskie, gmin: Olkusz, Skała i Wielka Wieś oraz powiatu gliwickiego. Również Urząd Marszałkowski Województwa Małopolskiego dofinansował oznakowanie i promocję odcinków Drogi św. Jakuba na terenie Małopolski, tj. Małopolską Drogę św. Jakuba, Beskidzką Drogę św. Jakuba i Drogę św. Jakuba Via Regia.

Urząd Marszałkowski Województwa Podkarpackiego dofinansował oznakowanie i promocję Podkarpackiej Drogi św. Jakuba Via Regia, zlecając to zadanie Stowarzyszeniu „Pro Carpathia”, które było partnerem regionalnym Stowarzyszenia „Przyjaciele Dróg św. Jakuba”. Oznakowanie jednak szlaku przez Stowarzyszenie „Pro Carpathia” należy ocenić negatywnie i choć formalnie to stowarzyszenie jest zarządcą szlaku, to de facto opiekę nad szlakiem sprawują bardzo aktywnie członkowie Bractwa św. Jakuba przy Sanktuarium Bożego Grobu w Przeworsku, którzy też poprawiają jego oznakowanie. Sytuacja z oznakowaniem Podkarpackiej Drogi św. Jakuba pokazuje, że projekty realizowane przez osoby nieznające specyfiki Camino de Santiago, choć wspierane dofinansowaniem ze środków publicznych, nie zawsze przynoszą spodziewane efekty.

Na podkreślenie zasługuje także działalność Stowarzyszenia „Przyjaciele Dróg św. Jakuba w Polsce” - ponadregionalnego stowarzyszenia, które od 2009 r. zaangażowało się w oznakowanie i promocję wielu odcinków Drogi św. Jakuba w Polsce, umiejętnie pozyskując środki finansowe od wielu samorządów terytorialnych ${ }^{4}$.

Największym projektem realizowanym jak dotąd w polskiej sieci Camino de Santiago był zrealizowany w latach 2011-2014 projekt pod nazwą „Re-vitalisation of the European Culture Route in the South Baltic Area Pomerania Way of St. James” - „RECReate - Rewitalizacja Europejskiego Szlaku Kulturowego w obszarze Południowego Bałtyku - Pomorska Droga św. Jakuba”. Projekt został zatwierdzony 29 września 2010 r. przez Komitet Sterujący Programu Współpracy Transgranicznej Południowy Bałtyk, a jego partnerami są: Gmina i Miasto Lębork (partner wiodący), Samorząd Powiatu Lęborskiego, Samorząd Województwa Pomorskiego, „Fundacja „Szczecińska”, Pomorska Regionalna Organizacja Turystyczna, Samorząd Miasta Kretynga, Uniwersytet Gdański, Uniwersytet im. Ernsta Moritza Arndta w Greifswaldzie i Elbląski Klaster Turystyczny. Budżet projektu wyniósł 1,4 mln euro, z czego 85\% pochodziło z Programu Europejskiej Współpracy Terytorialnej Południowy Bałtyk. Uroczyste otwarcie Pomorskiej Drogi św. Jakuba odbyło

\footnotetext{
${ }^{4}$ https://www.camino.net.pl/informacje (2017, 20 października)
} 
się podczas V Jarmarku Jakubowego w Szczecinie 28 lipca 2013 r. Szlak ten prowadzi z Kretyngi na Litwie przez Królewiec w obwodzie kaliningradzkim, a następnie Frombork, Elbląg, Gdańsk, Kartuzy, Lębork, Łebę, Słupsk, Koszalin, Kołobrzeg do Świnoujścia, gdzie łączy się z już istniejącą niemiecką częścią Via Baltica. Szlak przebiega przez obszar trzech województw: warmińsko-mazurskiego, pomorskiego oraz zachodnio-pomorskiego (Duda M., Duda T., 2013).

\section{Przedsiębiorczość jako czynnik funkcjonowania i rozwoju polskich odcinków Drogi św. Jakuba}

Wytyczenie i oznakowanie ponad 6 tys. km Drogi św. Jakuba było pierwszym i fundamentalnym krokiem do dalszego funkcjonowania szlaku. O rozwoju poszczególnych odcinków polskiego Camino de Santiago decyduje szereg czynników religijnych, społecznych, ekonomicznych i politycznych. Kluczowe znaczenie ma postawa przedsiębiorcza osób opiekujących się szlakiem, a więc wspomnianych już wcześniej caminowiczów, członków bractw i stowarzyszeń św. Jakuba, duszpasterzy pracujących w placówkach kościelnych przy szlaku, a także lokalnych przedsiębiorców. W dalszym rozwoju Szlaku Jakubowego w Polsce ogromne znaczenie ma też oczywiście ranga drogi - najważniejszego obecnie szlaku pielgrzymkowego i kulturowego na świecie, a także jego ogromne dziedzictwo religijne, historyczne i kulturowe. Camino de Santiago nazywane jest „główną ulicą Europy”, „drogą życia”, „drogą wiary” oraz „drogą nawrócenia i pokory”. O imponującej popularności Drogi św. Jakuba decyduje indywidulany charakter wędrowania - pielgrzymowania tym szlakiem. Droga św. Jakuba jest niezwykłą przestrzenią spotkania z samym sobą, spotkania z Bogiem, spotkania z drugim człowiekiem - pielgrzymem na drodze, a także spotkania z osobą mieszkającą przy szlaku. Fundamentalne jednak znaczenie w odbiorze Camino de Santiago i przeżyciach z wędrówki tym szlakiem ma spotkanie z samym sobą - wędrówka „w głąb siebie”. Na szlaku pielgrzymkowym do grobu św. Jakuba w Santiago de Compostela bowiem, jak podkreślają caminowicze, „umiera stary człowiek i rodzi się nowy człowiek". Ta specyfika Drogi św. Jakuba powoduje, że na szlak wyruszają zarówno chrześcijanie, jak i osoby poszukujące wiary, przeżywające różne kryzysy, pragnące dokonać pewnej weryfikacji dotychczasowego życia, osoby niewierzące, a także wyznawcy innych religii. Szacunek do drugiej osoby, otwartość, życzliwość oraz wyciągnięta do pomocy dłoń to dominanty relacji międzyludzkich na Camino de Santiago. W ostatnich latach, zwłaszcza na odcinkach Drogi św. Jakuba w Europie Zachodniej, bardzo wyraźnie uwidoczniły się także zagrożenia mające wpływ na pielgrzymkowy charakter szlaku. Są nimi przede wszystkim komercjalizacja Drogi św. Jakuba, promowanie szlaku wyłącznie jako produktu turystycznego i odchodzenie od pielgrzymkowego charakteru szlaku (Mróz, 2016b).

Przeprowadzone badania wykazały zróżnicowany stopień postaw przedsiębiorczych na poszczególnych polskich odcinkach Drogi św. Jakuba. W dalszym rozwoju Camino de Santiago w Polsce kluczowe znaczenie należy przypisać przedsiębiorczości społecznej a więc działaniom podejmowanym przez członków Bractw św. Jakuba, stowarzyszeń i klubów miłośników Drogi św. Jakuba, duszpasterzy parafii pw. św. Jakuba i caminowiczów. Rozwój Szlaków Jakubowych w Polsce postępuje równolegle z rozwojem kultu św. Jakuba w parafiach pod wezwaniem tego apostoła i jest wzmacniany przez propagowanie inicjatyw caminowych przez rosnącą liczbę Polaków wracających z Hiszpanii 
po odbyciu wędrówki do grobu św. Jakuba (w 2016 r. Compostelkę otrzymało 3919 osób z Polski $\left.{ }^{5}\right)$.

Jednym z wyrazów przedsiębiorczości w zakresie rozwoju Drogi św. Jakuba w Polsce jest stale zwiększająca się liczba bractw św. Jakuba, stowarzyszeń i klubów przyjaciół Camino de Santiago. Obecnie ponad 800 osób w Polsce jest zrzeszonych w tego typu stowarzyszeniach religijnych i społecznych oraz organizacjach pozarządowych (tab. 1). W każdej z tych grup można wyróżnić lidera, którego postawa oraz realizowane projekty mają wpływ na rozwój Szlaku Jakubowego w regionie. Bez wątpienia sukcesem duszpasterzy i członków bractw św. Jakuba w rozwoju kultu św. Jakuba w Jakubowie, Szczyrku, Lęborku, Więcławicach Starych i Małujowicach było podniesienie świątyń parafialnych w tychże miejscowościach do rangi sanktuarium św. Jakuba (dekretem ordynariusza miejsca, stosownie z kanonem 1230 Kodeksu prawa kanonicznego).

Z każdym rokiem wzrasta liczba organizowanych imprez „Jakubowych” i „caminowych”. Są to wydarzenia o charakterze religijnym lub religijno-kulturowym („biesiady Jakubowe”, „dni Jakubowe”, „festyny Jakubowe”, „festiwale Jakubowe”, „jarmarki Jakubowe", wystawy fotografii o Camino de Santiago, koncerty pieśni Jakubowych), turystycznym i sportowo-rekreacyjnym (rajdy i biegi Drogą św. Jakuba) oraz naukowym (sesje, sympozja, konferencje naukowe). Coraz częściej z inicjatywą zorganizowania tego typu imprez i wydarzeń wychodzą osoby niezwiązane z Camino de Santiago - m.in. studenci, nauczyciele, kluby PTTK. Od kilku lat bractwa św. Jakuba w Przeworsku, Szczyrku, Toruniu, Więcławicach Starych, a także Konfraternia Świętego Apostoła Jakuba Starszego przy Katedrze Polowej Wojska Polskiego w Warszawie oraz Kluby Przyjaciół Drogi św. Jakuba w Będzinie, Elblągu, Lubaniu, Lęborku, Miłosławiu i Zabrzu organizują weekendowe lub niedzielne grupowe przejścia i pielgrzymki Drogą św. Jakuba pod nazwą „Niedzielne Pielgrzymowanie Drogą św. Jakuba”, „Rowerowy Weekend po Via Regia”, „Weekend na Drodze św. Jakuba”, „Sobota na Camino”, „Caminowy pieszy tramwaj”, „Niedziela na Drodze św. Jakuba” czy też „Rajd Szlakiem św. Jakuba”. Działania związane m.in. z organizacją przejść Drogą św. Jakuba podejmują także inne stowarzyszenia, kluby i fundacje. Niektóre z imprez mają rangę międzynarodową, jak choćby organizowany w Lęborku „Międzynarodowy Zlot Jakubów”.

Inicjatywy organizowane non profit są wspierane przez władze samorządowe. Te działania mają na celu aktywizację lokalnej społeczności w rozwijaniu Drogi św. Jakuba przez m.in. tworzenie miejsc noclegowych dla caminowiczów, nadzór nad oznakowaniem i bazą informacyjną itp.

Droga św. Jakuba w Polsce jest przestrzenią, w której organizowane są także wydarzenia religijne i sportowe niezwiązane stricte z kultem św. Jakuba, a które cieszą się w ostatnich latach dużą popularnością wśród polskiego społeczeństwa, jak choćby ekstremalne drogi krzyżowe, nocne drogi krzyżowe, pochody Trzech Króli, pielgrzymki gwiaździste czy też biegi, półmaratony i sztafety. Na wielu odcinkach Camino de Santiago zorganizowano w ostatnich latach szereg imprez biegowych, a do cieszących się największą frekwencją należy zaliczyć: „Bieg uliczny św. Jakuba Apostoła” w Lęborku, „Półmaraton Jakubowy” w Olsztynie, „Małopolski Bieg Drogą św. Jakuba” organizowany w sanktuarium św. Jakuba w Więcławicach Starych, „Bieg Podkarpacką Drogą św. Jakuba” organizowany

\footnotetext{
${ }^{5}$ https://oficinadelperegrino.com/wp-content/uploads/2016/02/peregrinaciones2016.pdf (2017, 20 października)
} 
w Przeworsku i „Pielgrzymkę biegiem do św. Jakuba” organizowaną przez Parafię pw. św. Jakuba w Łebie.

Zdecydowana większość polskich odcinków Drogi św. Jakuba doskonale nadaje się do pielgrzymowania konno. Tego typu podróżowanie do grobu Apostoła Jakuba jest bardzo popularne w Hiszpanii (Camino a Caballo), gdzie przygotowana jest bardzo dobra infrastruktura turystyczna. W Polsce pielgrzymki konne organizowane są m.in. na Camino Polaco (przez gminę Chocianów), Małopolskiej Drodze św. Jakuba, Podkarpackiej Drodze św. Jakuba (przez gminę Przeworsk) i Nadwarciańskiej Drodze św. Jakuba. Na polskich odcinkach Szlaku Jakubowego organizowane są także pielgrzymki, których nie spotkamy na Camino de Santiago w krajach Europy Zachodniej. Są to pielgrzymki - spływy kajakowe organizowane na rzece Nysie - wzdłuż Nyskiej Drogi św. Jakuba oraz na Camino Polaco (na rzece Drwęca), a także Pielgrzymki Narciarskie Beskidzką Drogą św. Jakuba organizowane od 2011 r., każdego roku na przełomie stycznia i lutego przez Bractwo św. Jakuba w Szczyrku.

Jednym z kluczowych problemów związanych z funkcjonowaniem Drogi św. Jakuba jest słaby stopień rozwoju bazy turystycznej. Rozbudowa infrastruktury turystyczno-pielgrzymkowej, a więc przygotowanie albergue (schronisk dla pielgrzymów), a także miejsc do odpoczynku, przepakowania bagażu, spożycia posiłku i schronienia przed niekorzystnymi warunkami pogodowymi na szlaku (schrony, wiaty turystyczne, ławki, stoły, kosze na śmieci) to jeden $\mathrm{z}$ ważnych elementów funkcjonowania szlaku. W ostatnich latach rozbudowana została przede wszystkim baza informacyjna o Camino de Santiago. Powstały także pierwsze albergue dla caminowiczów, m.in. dzięki adaptacji obiektów parafialnych lub gminnych na bazę noclegową. Przykładem są schroniska parafialne w Lęborku, Olsztynie, Sączowie i w Więcławicach Starych, czy też albergue powstałe dzięki przedsiębiorczości władz gminy Pałecznica w Pałecznicy. Z kolei od 1 września 2017 r. w budynku dawnej Szkoły Podstawowej Nr 2 im. Europejskich Dróg Świętego Jakuba w Lubaniu (Lubań, ul. Dolna 8), za sprawą członków Lubańskiego Klubu Przyjaciół Camino i ks. Marka Kurzawy - Proboszcza parafii pw. Narodzenia NMP w Lubaniu-Uniegoszczy - funkcjonuje schronisko dla pielgrzymów.

Ciekawym rozwiązaniem jest także stworzenie w parafiach przy szlaku tzw. muszelkowej sieci domów przyjaznych pątnikom, w których caminowicz po okazaniu Paszportu pielgrzyma uzyskuje nocleg. Taka muszelkowa sieć domów przyjaznych pielgrzymom funkcjonuje od 2008 r. w Parafii pw. św. Jakuba w Więcławicach Starych. Stowarzyszenie na rzecz Rozwoju i Promocji Gminy Pałecznica „Muszelka” przy wsparciu środków Województwa Małopolskiego w ramach otwartego konkursu ofert z dziedziny turystyki pn. „Małopolska gościnna” zrealizowało w 2014 r. zadanie publiczne pn. „Przystań Pielgrzyma na Szlaku św. Jakuba” na terenie powiatu proszowickiego. Efektem końcowym realizowanych prac był montaż dwóch przystani - wiat turystycznych dla pielgrzymów na terenie gminy Pałecznica w miejscowościach: Winiary oraz Lelowice Kolonia. Podobny projekt został wykonany w Parafii pw. Matki Bożej Częstochowskiej w Duninowie, gdzie powstał tzw. „Przystanek Jakubowy”.

Oznakowanie Drogi św. Jakuba stwarza również nowe możliwości rozwoju turystyki religijnej oraz pielgrzymek do ośrodków pielgrzymkowych położonych bezpośrednio przy szlaku, jak i w bliskim sąsiedztwie drogi. Z drugiej strony infrastruktura turystyczna (głównie noclegowa i gastronomiczna) funkcjonująca przy sanktuariach wypełnia lukę w zagospodarowaniu turystycznym wielu polskich odcinków Camino de Santiago. 


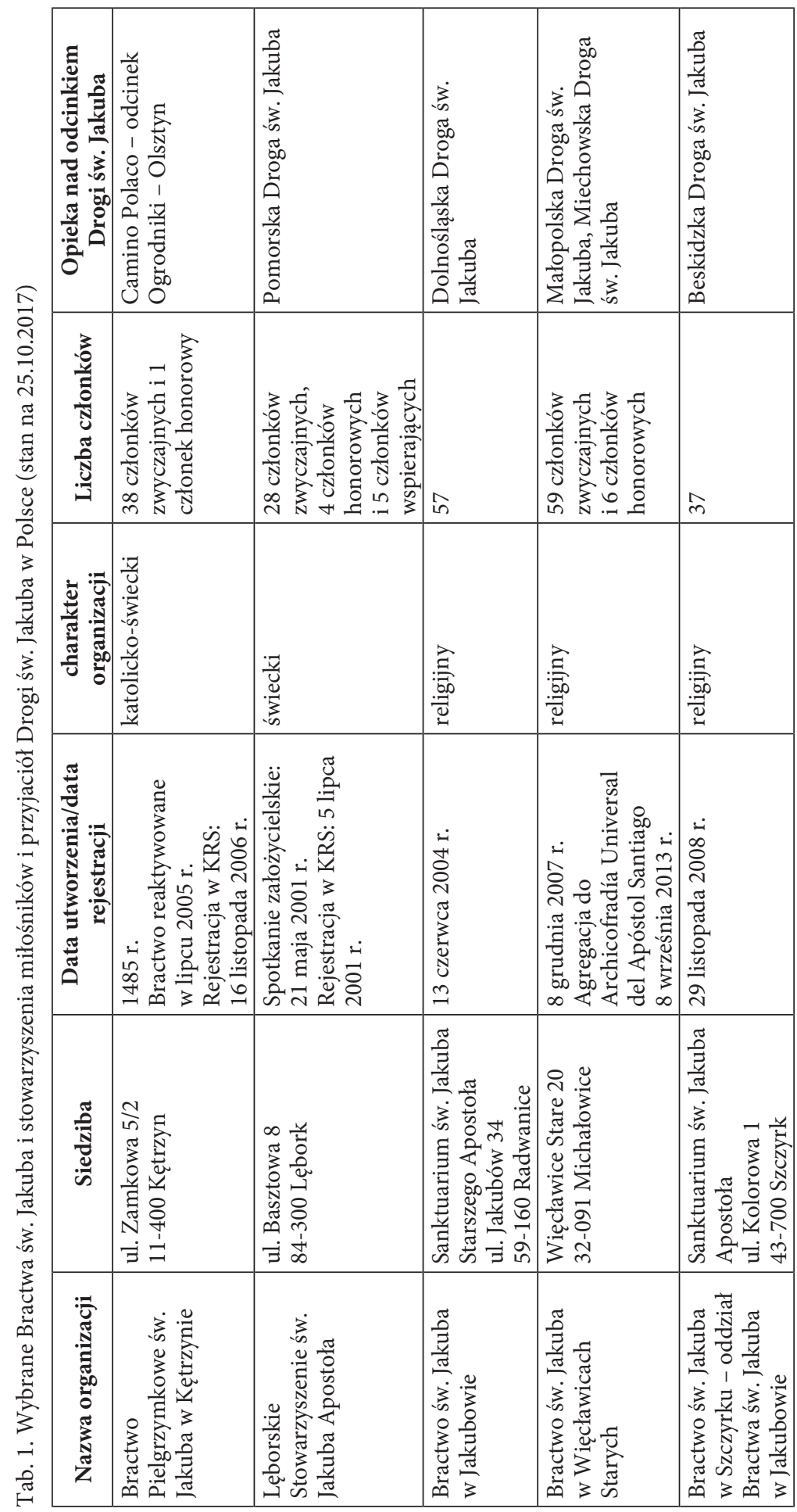




\begin{tabular}{|c|c|c|}
\hline 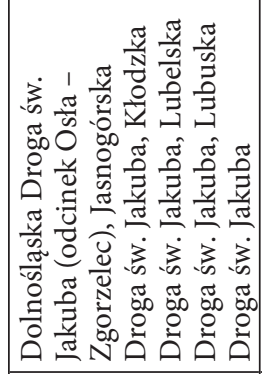 & 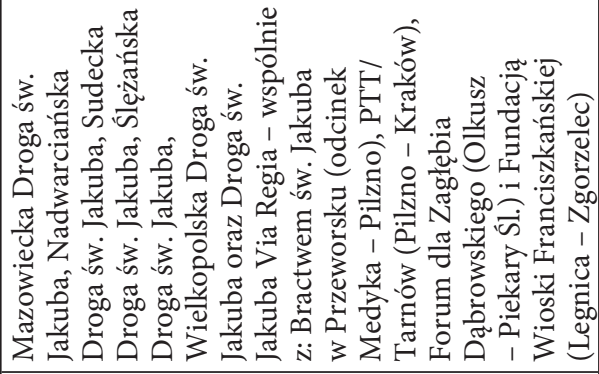 & 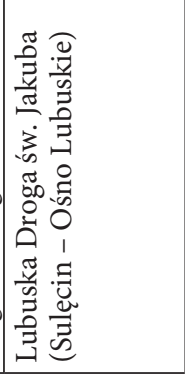 \\
\hline I্ & & . \\
\hline 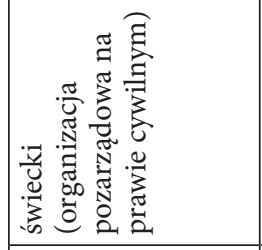 & & 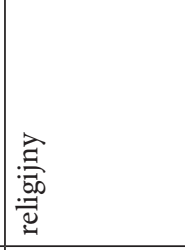 \\
\hline 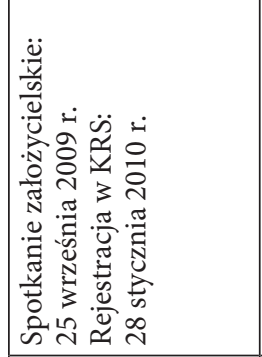 & & 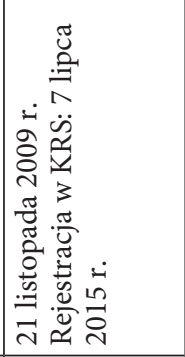 \\
\hline 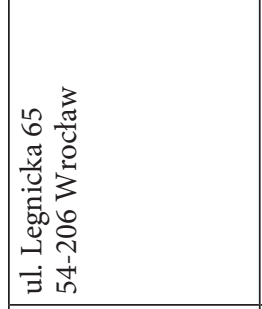 & & 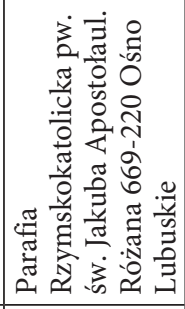 \\
\hline 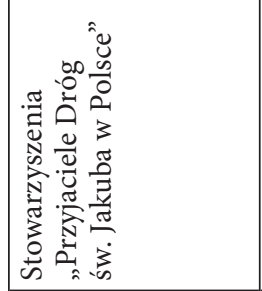 & & 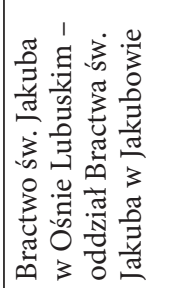 \\
\hline
\end{tabular}




\begin{tabular}{|c|c|c|c|c|}
\hline 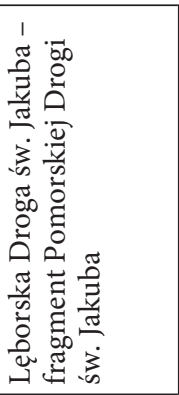 & 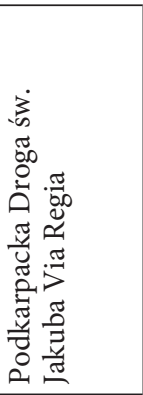 & 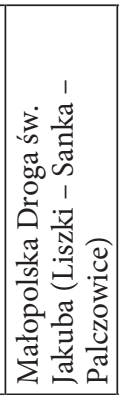 & 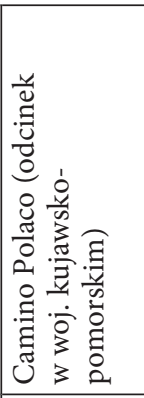 & 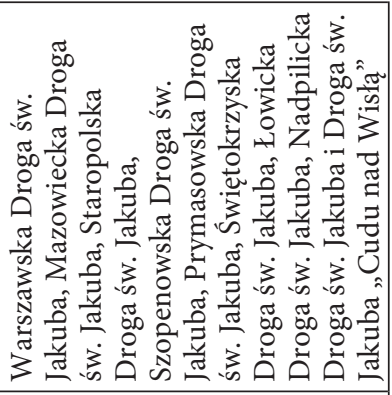 \\
\hline$\Xi$ & $\stackrel{2}{\sim}$ & 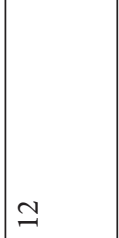 & $F$ & 色 \\
\hline 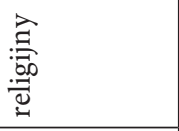 & 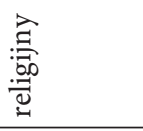 & 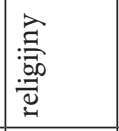 & 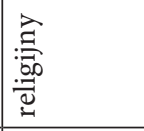 & 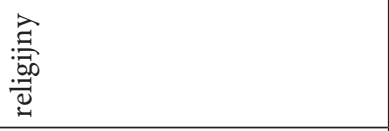 \\
\hline 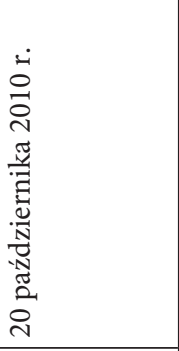 & 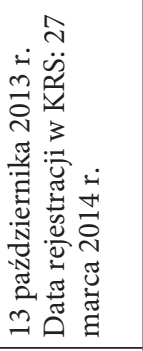 & 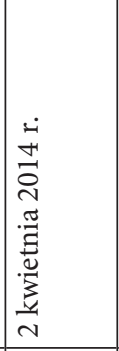 & 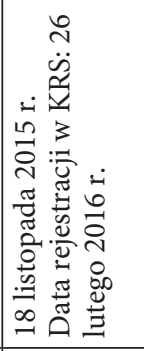 & 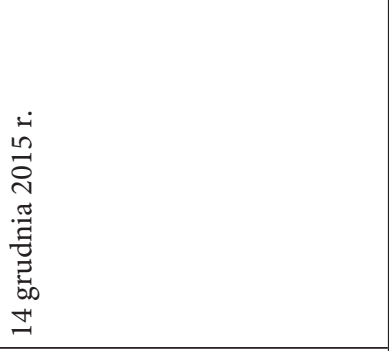 \\
\hline 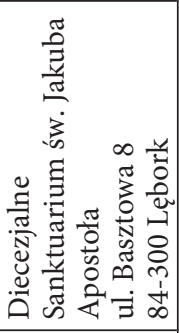 & 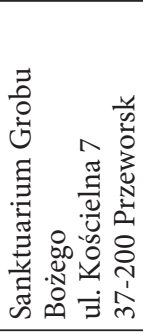 & 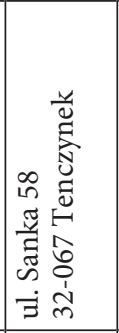 & 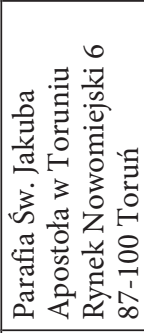 & 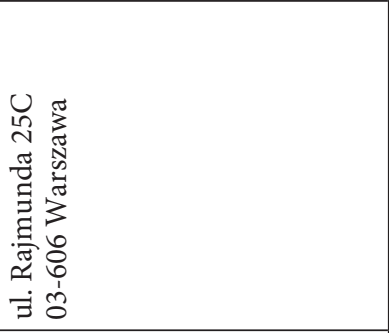 \\
\hline 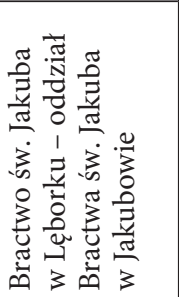 & 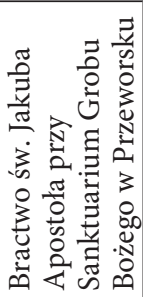 & 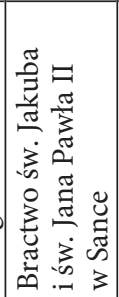 & 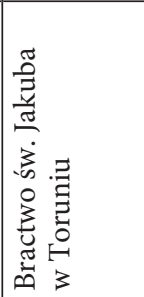 & 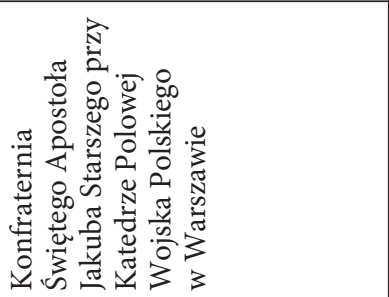 \\
\hline
\end{tabular}




\begin{tabular}{|c|c|c|c|c|c|}
\hline & 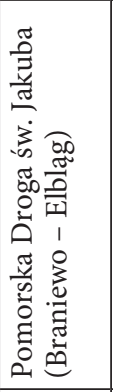 & 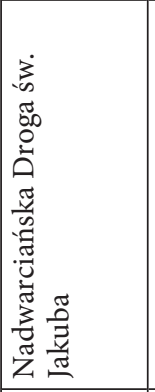 & 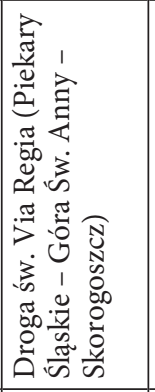 & 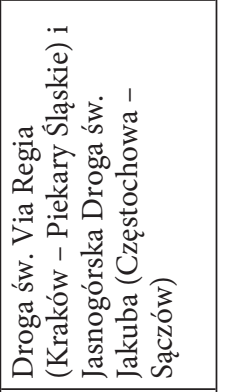 & 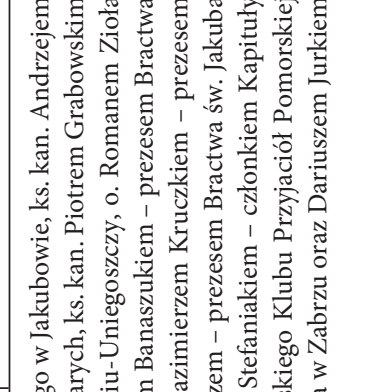 \\
\hline$\stackrel{\vartheta}{\exists}$ & $\stackrel{\infty}{\sim}$ & \& & $\simeq$ & 아 & 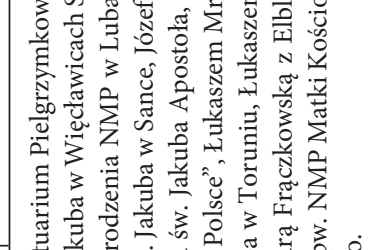 \\
\hline 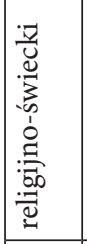 & 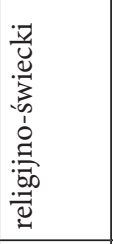 & 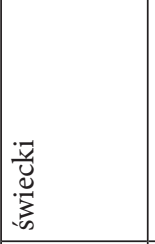 & 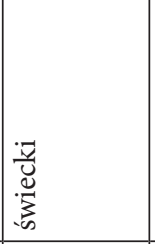 & 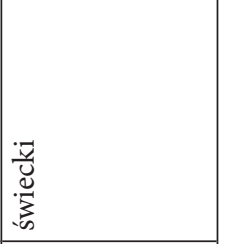 & 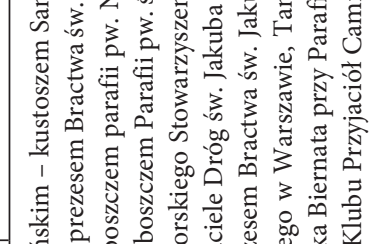 \\
\hline 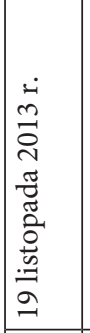 & 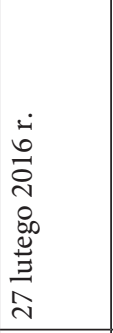 & 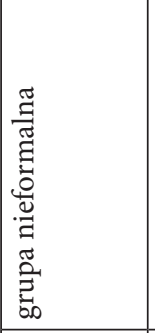 & 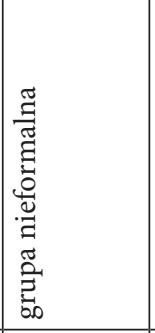 & 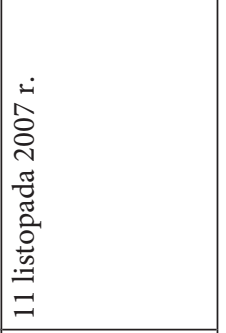 & 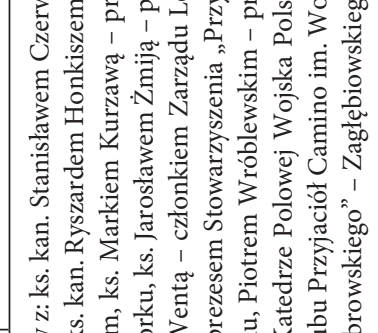 \\
\hline 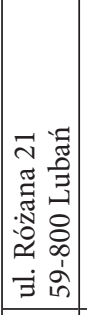 & $\begin{array}{l}\text { 兽 } \\
\text { 竞 }\end{array}$ & 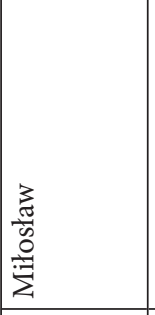 & 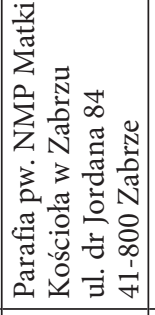 & 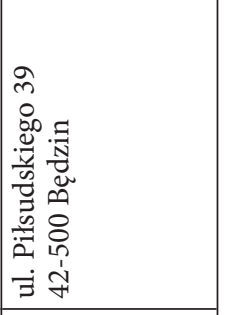 & 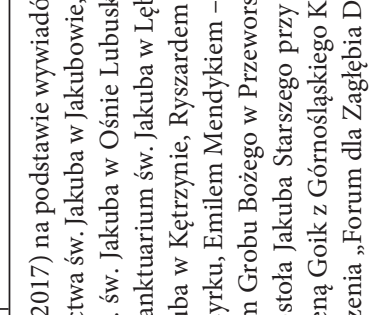 \\
\hline 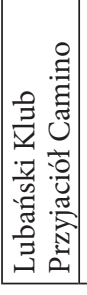 & 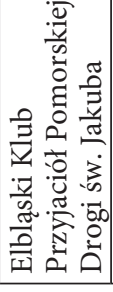 & 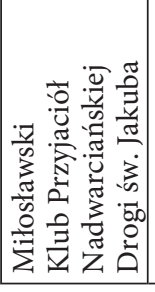 & 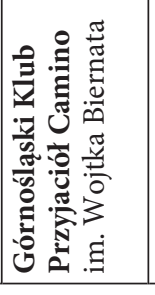 & 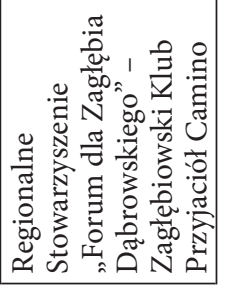 & 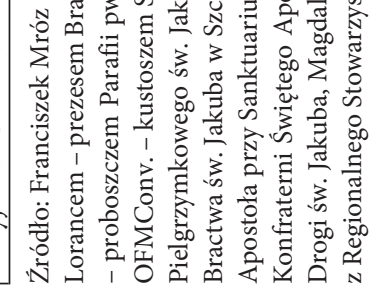 \\
\hline
\end{tabular}


Funkcjonowanie Drogi św. Jakuba doskonale wpisuje się także w strategie rozwoju turystyki kulturowej i turystyki transgranicznej w jednostkach przestrzennych.

Z inicjatywy Lęborskiego Stowarzyszenia św. Jakuba w Lęborku przy wsparciu samorządu miasta Lęborka (szczególnie Ryszarda Wenty - kuratora Pomorskiej Drogi św. Jakuba) opracowano i wydrukowano polskojęzyczną wersję Paszportu pielgrzyma, który jest akceptowany w Centrum Obsługi Pielgrzyma przy archikatedrze w Santiago de Compostela. O sukcesie tego przedsięwzięcia może świadczyć fakt, że od stycznia do października 2017 r. Lęborskie Stowarzyszenie św. Jakuba rozprowadziło ponad 1000 egz. tego paszportu. Należy podkreślić, że wiele stowarzyszeń i bractw św. Jakuba w Polsce przygotowało dla pielgrzymów „regionalne” Paszporty pielgrzyma, które są wykorzystywane przez caminowiczów zarówno na polskich, jak i na hiszpańskich odcinkach Camino de Santiago.

Caminowicze pielgrzymujący - wędrujący wybranymi odcinkami Drogi św. Jakuba w Polsce mogą uzyskać certyfikaty na wzór hiszpańskiej Compostelki. Dla przykładu Bractwo św. Jakuba w Toruniu przygotowało certyfikat o nazwie Iacobeum Thoruniensis dla każdego pielgrzyma, który pokona pieszo stukilometrowy odcinek Camino Polaco i nawiedzi kościół pw. św. Jakuba w Toruniu. Z kolei Bractwo Pielgrzymkowe św. Jakuba Starszego w Kętrzynie wręcza tzw. Warmiankę osobom, które przeszły lub przejechały rowerem stukilometrowy odcinek Camino Polaco do bazyliki św. Jerzego w Kętrzynie. W propagowanie idei wędrówek Drogą św. Jakuba włączają się również oddziały PTTK, przygotowujące odznaki turystyczne św. Jakuba (Odznaka Turystyczno-Krajoznawcza „Drogami Świętego Jakuba” ustanowiona w 2007 r. przez Zarząd Oddziału PTTK w Szamotułach; Kujawsko-Pomorska Odznaka św. Jakuba ustanowiona w 2012 r. przez Oddział Miejski PTTK w Toruniu; Odznaka Pomorskiej Drogi św. Jakuba ustanowiona w 2014 r. przez Prezydium Zarządu Regionalnego Oddziału PTTK w Słupsku; Odznaka Krajoznawcza „Zachodniopomorska Droga Świętego Jakuba” ustanowiona przez Zarząd Oddziału Wojskowego PTTK w Kołobrzegu).

Bardzo ważnym przedsięwzięciem podjętym przez Urząd Marszałkowski Województwa Kujawsko-Pomorskiego było przystąpienie w 2016 r. do Europejskiej Federacji Szlaku św. Jakuba. Federacja w imieniu Rady Europy promuje Camino de Santiago jako europejski szlak kulturowy oraz ma uprawnienia do poszerzania europejskiej sieci Szlaków Jakubowych o odcinki znajdujące się w kolejnych krajach. Akces ten skutkował oficjalnym włączeniem Polski do sieci Europejskich Szlaków Kulturowych ${ }^{6}$.

Z kolei w kwietniu 2017 r. Polska przystąpiła do Poszerzonego Porozumienia Częściowego w sprawie szlaków kulturowych Rady Europy. Zasadniczym punktem współpracy w ramach tego porozumienia jest rozwój szlaków o symbolicznym znaczeniu dla europejskiej historii i kultury. Dzięki temu akcesowi nasz kraj będzie mógł wzmocnić współpracę w zakresie rozwoju Europejskich Szlaków Kulturowych, popularyzować dziedzictwo kulturowe i historię oraz rozwijać turystykę kulturową w regionach.

Analizując działania przedsiębiorcze podejmowane na polskich odcinkach Drogi św. Jakuba, należy koniecznie zwrócić uwagę na działalność Pracowni Szlaku św. Jakuba, która funkcjonuje od 2013 r. przy Wydziale Teologicznym Uniwersytetu Mikołaja Kopernika w Toruniu pod kierownictwem ks. prof. Piotra Roszaka. Pracownię tworzą pracownicy

\footnotetext{
${ }^{6}$ https://www.coe.int/en/web/cultural-routes/the-santiago-de-compostela-pilgrim-routes; http://www. saintjamesway.eu/carte-le-chemin-en-europe/pologne/ (2017, 24 października)
} 
naukowi z Polski i z zagranicy oraz miłośnicy Camino de Santiago. Pracownia bardzo aktywnie włącza się w promocję odcinka Camino Polaco na terenie województwa kujawsko-pomorskiego, organizuje i propaguje wydarzenia naukowe, dydaktyczne, religijne i kulturalne związane ze Szlakiem Jakubowym. W latach 2015-2016 pracownicy naukowi skupieni wokół Pracowni Szlaku św. Jakuba zrealizowali grant Narodowego Centrum Nauki pn. „Camino de Santiago i grób św. Jakuba: od historii do hermeneutyki wiary”. W 2017 r. Pracownia przygotowała także film o Camino Polaco w województwie kujawsko-pomorskim pt. Grunt to Droga, którego reżyserem była Teresa Kudyba. Działalność Pracowni Szlaku św. Jakuba została doceniona w konkursie rządu regionalnego Galicji w Hiszpanii, w którym otrzymała ona 10 tys. euro nagrody w kategorii instytucji naukowych ${ }^{7}$. Warto również zaznaczyć, że Uniwersytet Mikołaja Kopernika w Toruniu był pierwszą uczelnią w Polsce wpisaną do projektu „Campus Stellae” i otrzymał Akademicką Akredytację Jakubową ${ }^{8}$. „Campus Stellae” jest ważnym ogniwem łączącym młodzież studencką oraz pracowników naukowo-dydaktycznych szkół wyższych z ideą pielgrzymowania - wędrówek po Drodze św. Jakuba. Projekt ten rozwija się od 2002 r. dzięki Stowarzyszeniu Absolwentów Uniwersytetu Nawarry (Asociación ALUMNI - Universidad de Navarra), które współpracuje z innymi uniwersytetami hiszpańskimi położonymi na Drodze Francuskiej. Głównym celem „Campus Stellae” jest propagowanie Camino de Santiago wśród międzynarodowej społeczności uniwersyteckiej. Rozwijanie idei tzw. pielgrzymki akademickiej Drogą św. Jakuba w ramach Akademickiej Akredytacji Jakubowej jest bardzo dobrym przykładem przedsiębiorczości intelektualnej. Cieszyć może fakt, że Akademicką Akredytację Jakubową otrzymał także Uniwersytet Papieski Jana Pawła II w Krakowie, który wspólnie z Instytutem Geografii Uniwersytetu Pedagogicznego im. Komisji Edukacji Narodowej w Krakowie, Wydziałem Teologicznym Uniwersytetu Mikołaja Kopernika w Toruniu i Bractwem św. Jakuba w Więcławicach Starych organizuje cykliczną międzynarodową konferencję naukową poświęconą problematyce historii i funkcjonowania Drogi św. Jakuba oraz kultu tego apostoła w Europie. Referaty wygłoszone podczas 10 międzynarodowych konferencji naukowych, które odbyły się w latach 2008-2017 zostały opublikowane w 10 tomach prac pokonferencyjnych, które łącznie zwierają 184 artykuły naukowe i 11 komunikatów.

Bardzo ciekawym przykładem związanym ze społeczną odpowiedzialnością biznesu jest stworzenie portalu informacyjnego CaminoDeLaVida o Drodze św. Jakuba w Europie. Autorem tego projektu i administratorem strony jest Piotr Drzewiecki. Na portalu zamieszczane są stale aktualizowane wiadomości dotyczące funkcjonowania odcinków Szlaku Jakubowego, praktyczne wskazówki, kalendarium ważnych wydarzeń na polskich odcinkach Camino de Santiago i szereg informacji przydatnych pielgrzymom. Portal CaminoDeLaVida pełni funkcję internetowego biura informacji o Drodze św. Jakuba, promującego zrównoważone i świadome pielgrzymowanie Szlakami Jakubowymi.

Rozwój pielgrzymowania i wędrówek Drogą św. Jakuba w Polsce jest impulsem dla przedsiębiorców do podejmowania działalności gospodarczej w zakresie produkcji przedmiotów nawiązujących do idei Camino de Santiago. Jako przykład należy podać produkcję skarpetek marki Camino Madalena - skarpet przygotowanych specjalnie dla pielgrzymów, wyróżniających się odpowiednim składem surowcowym, technologią

\footnotetext{
${ }^{7}$ https://www.umk.pl/wiadomosci/?id=20171011124551 (2017, 24 października)

${ }^{8}$ www.campus-stellae.org/cpolonia.html\#regia / (2017, 25 października)
} 
produkcji oraz wyjątkowym wzornictwem, które nawiązuje do Drogi św. Jakuba. Wzór jest zastrzeżony w Unii Europejskiej. Skarpetki marki Camino Madalena, której właścicielem jest Magdalena Goik, dystrybuowane są w Hiszpanii, Portugalii i na Ukrainie. Warto podkreślić, że pomysł na produkcję tego typu skarpetek zrodził się u Magdaleny Goik po przejściu przez nią po raz pierwszy odcinka Camino de Santiago do grobu św. Jakuba w Santiago de Compostela. Z kolei firma Galicya Sp. z o. o., która pozyskuje i sprzedaje naturalną wodę mineralną o charakterze wodorowęglanowo-wapiennym, pochodzącą z ujęcia znajdującego się w Narolu (w obrębie Południoworoztoczańskiego Parku Krajobrazowego i Puszczy Solskiej) rozpoczęła pod koniec 2017 r. produkować wodę pod nazwą „Buen Camino”.

Wnioski

Z przeprowadzonych badań wynika, że projektowanie, wytyczanie i oznakowanie już niemal 6,5 tys. km Camino de Santiago w Polsce jest przede wszystkim zasługą grup miłośników Drogi św. Jakuba, caminowiczów, członków bractw św. Jakuba, klubów miłośników Camino oraz stowarzyszeń Jakubowych, a także duszpasterzy pracujących w placówkach przy szlaku. W zdecydowanej większości była to inicjatywa „oddolna” i wyraz społecznej przedsiębiorczości dziesiątek osób. Dopiero na kolejnych etapach rozwoju Drogi św. Jakuba w poszczególnych regionach stopniowo w projekty „caminowe” włączały się władze samorządów terytorialnych. Dzięki tym projektom Polska dołączyła do liderów caminowych w Europie.

Działalność przedsiębiorcza (bractw, grup, stowarzyszeń, organizacji turystycznych) opiekujących się wybranym odcinkiem Drogi św. Jakuba jest jednym z fundamentalnych czynników mających wpływ na rozwój Camino de Santiago w regionie, przez który przechodzi szlak. Ogromnie istotna w rozwoju polskich Szlaków Jakubowych jest także postawa liderów caminowych - ich cechy osobowe oraz umiejętność współpracy ze środowiskiem wewnętrznym i otoczeniem. Do dalszego rozwoju szlaku konieczne są: przyjazny stosunek władz samorządowych i kościelnych (na szczeblu diecezjalnym i parafialnym), opieka duszpasterska w placówkach przy szlaku, zaangażowanie młodzieży w idee caminowe, a także poszukiwanie i wprowadzanie nowych pomysłów, rozwiązań i projektów - innowacyjność oraz ekspansywność. Osoby i organizacje podejmujące się realizacji szeregu zadań i inicjatyw mających na celu rozwój Camino de Santiago w Polsce, powinny przede wszystkim jednak pamiętać, że żaden projekt nie może prowadzić do zatracenia religijnego charakteru tego szlaku.

\section{Literatura}

References

Antkowiak, W. (2007). Szlak św. Jakuba. Polska Droga. Odcinek Olsztyn - Toruń. Przewodnik dla pielgrzymów i turystów. Toruń.

Bielicki, T., Roszak, P. (2012). U progu Camino. Przewodnik po kujawsko-pomorskim odcinku Szlaku św. Jakuba. Toruń: Wydawnictwo Naukowe UMK.

Bożek, R., Czajka, W., Kazimierczak, J., Madej-Janiszek, R., Pawlikowski, J., Przygoda-Golenia, A., Skwierczyńska-Mizerska, B., Stefaniak, Ł. (2015). Droga Świętego Jakuba Cudu nad Wisłą. 
Przewodnik pielgrzyma. Warszawa: Konfraternia Świętego Apostoła Jakuba Starszego przy Katedrze Polowej Wojska Polskiego w Warszawie.

Duda, M., Duda, T. (red.) (2013). Pomorska Droga św. Jakuba. Przewodnik turystyczny. Szczecin: Fundacja Szczecińska.

Hass, W. (2008). Z Jakubowa do Santiago de Compostela. Szlak, bractwo, sanktuarium. W: A Jackowski, F. Mróz, I. Hodorowicz (red.), Drogi św. Jakuba w Polsce - stan badań i organizacja. Kraków: Wydawnictwo „Czuwajmy”, 95-102.

Hołub, J.M., Mróz, Ł. (2013). Droga św. Jakuba Via Regia, Podkarpackie - przewodnik pielgrzyma i turysty. Jarosław: Stowarzyszenie „Przyjaciele Dróg św. Jakuba w Polsce”.

Kazimierczak, J. (2015). Warszawska Droga Świętego Jakuba Większego Apostoła. Przewodnik dla pielgrzymów i turystów. Warszawa: Jerzy Grzegorz Kazimierczak.

Madej-Janiszek, R. (2015). Mazowiecka Droga św. Jakuba. W: P. Roszak, F. Mróz (red.), Droga św. Jakuba w Polsce - historia, teraźniejszość i przyszłość. W 10. rocznicę otwarcia pierwszego polskiego odcinka Camino de Santiago. Kraków: Wydawnictwo „Czuwajmy”, 306-309.

Mendyk, E., Mróz, F. (2009). Droga św. Jakuba w Polsce. Kalendarium wydarzeń w latach 2004-2009. W: I. Hodorowicz, F. Mróz (red.), Pielgrzymi na Drodze św. Jakuba. Przeszłość i teraźniejszość. Nowy Targ: Wydawnictwo Podhalańskiej Państwowej Wyższej Szkoły Zawodowej, 77-85.

Mróz, F. (2014). Małopolska Droga św. Jakuba - geneza, rozwój, nowe wyzwania i perspektywy rozwoju. Rozprawy Naukowe Akademii Wychowania Fizycznego we Wrocławiu, 47(2014), 22-31.

Mróz, F. (2015). Droga św. Jakuba w Polsce - geneza i rozwój - w 10. rocznicę otwarcia pierwszego szlaku jakubowego. W: A. Wyrwa (red.), Camino de Santiago. Szkice historyczne do peregrynacji i dziejów kultuśw. Jakuba Apostoła Większego (wydanie II). Lednica: Muzeum Pierwszych Piastów na Lednicy, 65-95.

Mróz, F. (2016a). Pielgrzymowanie polskimi odcinkami Drogi św. Jakuba na początku XXI wieku. W: P. Roszak, W. Rozynkowski (red.), Camino Polaco. Teologia-Sztuka-Historia-Teraźniejszość, t. 3. Toruń: Wydawnictwo Naukowe Uniwersytetu Mikołaja Kopernika w Toruniu, 177-202.

Mróz, F. (2016b). Znaczenie europejskich szlaków pielgrzymkowych w budowaniu tożsamości Europy - przeszłość i teraźniejszość. W: M.C. Hastetter, M. Ostrowski (red.), Pielgrzymi, drogi, święte miejsca. Duszpasterstwo w kontekście podróży. Kraków - Trumau: Wydawnictwo UNUM, 185-199.

Mróz, F., Bordun, O. (2016). The Origin and Functioning of the Lviv Way of St. James Via Regia and Its Importance in the Development of Pilgrimages and Religious Tourism at the Polish-Ukrainian Border. Annales Universitatis Paedagogicae Cracoviensis Studia Geographica, 10(2016), 120-138.

Mróz, F. (2017). How has Camino developed? Geographical and Historical Factors behind the Creation and Development of the Way of St. James in Poland. W: E. Alarcón, P. Roszak (red.), The Way of St. James: Renewing Insights. Navarra: Ediciones Universidad de Navarra, 59-80.

Stefaniak, Ł., Wasiak, E. (2017). Ze Świętym Jakubem do Świętego Józefa. Warszawa - Kalisz po Drogach Świętego Jakuba: Mazowieckiej, Szopenowskiej, Warszawskiej, Łowickiej. W: P. Roszak, F. Mróz, Ł. Mróz (red.), Dziedzictwo religijne i kulturowe Drogi św. Jakuba - w 30. rocznicę uznania szlaku za pierwszy Europejski Szlak Kulturowy. Kraków: Wydawnictwo „Czuwajmy”, 319-339.

Szeszko, R., Góralczyk P. (2015). Lubuska Droga św. Jakuba. Murowana Goślina - Stubice. Przewodnik Pielgrzyma. Wrocław: Stowarzyszenie „Przyjaciele Dróg św. Jakuba w Polsce”.

Zioło, Z. (2012). Procesy kształtowania miasta innowacyjnego. Studia. Polska Akademia Nauk. Komitet Przestrzennego Zagospodarowania Kraju, 141(2012), 39-60.

Franciszek Mróz, doktor, urodzony w 1975 r. w Przeworsku, geograf społeczno-ekonomiczny, pracownik naukowo-dydaktyczny (adiunkt) w Zakładzie Turystyki i Badań Regionalnych Instytutu Geografii Uniwersytetu Pedagogicznego w Krakowie. Wykładowca w Uniwersytecie Papieskim Jana Pawła II w Krakowie. Konsultor w Radzie ds. Migracji, Turystyki i Pielgrzymek Konferencji Episkopatu Polski. Członek Archicofradía Universal del Apóstol Santiago. Instruktor Krajoznawstwa Polski. Obecnie jego zainteresowania badawcze koncentrują się m.in. wokół zagadnień związanych z pielgrzymowaniem, turystyką religijną i turystyką kulturową w Polsce, genezą i funkcjonowaniem 
ośrodków pielgrzymkowych w Europie, a także europejskimi szlakami kulturowymi, ze szczególnym uwzględnieniem Camino de Santiago - Drogi św. Jakuba. Jest autorem ponad 90 publikacji naukowych i ponad 50 publikacji popularno-naukowych z tego zakresu, a także redaktorem 13 prac zbiorowych. Od 2008 r. jest współorganizatorem corocznych międzynarodowych konferencji naukowych poświęconych problematyce historii i funkcjonowania Drogi św. Jakuba w Europie. Jest szczęśliwym mężem i ojcem trójki wspaniałych dzieci: Piotra (16 lat), Michała (14 lat) i Anny (9 lat). Interesuje się krajoznawstwem, fotografią i sportem.

Franciszek Mróz, PhD, Socio-economic geographer born in 1975 in Przeworsk, an academic (assistant professor) at the Department of Tourism and Regional Research of the Institute of Geography at the Pedagogical University of Cracow. Lecturer at the Pontifical University of John Paul II in Cracow. Consultant in the Migration, Tourism and Pilgrimage Council of the Polish Episcopal Conference. Member of Archicofradía Universal del Apóstol Santiago. Instructor of Polish cultural and regional studies. His present research interests are concentrated on, for example, issues related to pilgrimages, religious and cultural tourism in Poland, origins and functioning of pilgrimage centres in Europe, and European cultural routes, especially Camino de Santiago - the Way of St. James. He is the author of more than 90 publications and more than 50 popular science publications from this field as well as an editor of 13 collaborative publications. Since 2008, he has been the co-organiser of annual international scientific conferences devoted to the history and functioning of the Way of St. James in Europe. He is also a happy husband and the father of three wonderful kids: Piotr (16), Michał (14) and Anna (9). He is interested in cultural and regional studies, photography and sports.

\section{Adres/Address:}

Uniwersytet Pedagogiczny im. Komisji Edukacji Narodowej w Krakowie

Instytut Geografii

Zakład Turystyki i Badań Regionalnych

ul. Podchorążych 2

30-084 Kraków, Polska

e-mail: fmroz@up.krakow.pl 